\title{
Size of catch, reproduction and feeding of the small-eye smooth-hound, Mustelus higmani (Carcharhiniformes: Triakidae), in Margarita Island, Venezuela
}

\author{
Alejandro Tagliafico ${ }^{1,2}$, Iván Hernández-Ávila ${ }^{3,4}$, Salomé Rangel ${ }^{2,3}$, Néstor Rago ${ }^{5}$ \\ ${ }^{1}$ Escuela de Ciencias Aplicadas del Mar, Boca de Río, Universidad de Oriente, Venezuela. E-mail: tagliaficoa@ gmail.com \\ ${ }^{2}$ National Marine Science Centre, Southern Cross University, New South Wales, Australia. \\ ${ }^{3}$ Departamento de Ciencias, Núcleo de Nueva Esparta, Universidad de Oriente, Venezuela. \\ ${ }^{4}$ Laboratoire d'Environnement Profond, Ifremer, France. \\ ${ }^{5}$ Universidad Nacional de Costa Rica, Escuela de Biología, Heredia, Costa Rica.
}

\begin{abstract}
Summary: Mustelus higmani is categorized as "least concern" according to the red list of the International Union for Conservation of Nature, but gaps in population trends occur in most of its distribution range. In Venezuela, this species has local importance because it is part of typical dishes. The aim of this work is to analyse the population structure, reproduction and feeding of M. higmani from Margarita Island's artisanal fishery landings for management purposes. Between 2006 and 2008 , 2223 specimens were analysed: 1156 females $(24.8-88.4 \mathrm{~cm}$ total length [TL]) and 1067 males (20-69.2 cm TL). Temporal variations in sex ratio and length class structure were detected. Changes in body size were detected throughout different years of sampling. A decrease in TL and an increase in immature specimens in the catch were observed in 2008. Mean length at maturity $\left(\mathrm{L}_{50}\right)$ was estimated at $46.7 \mathrm{~cm}$ TL for females and $47.6 \mathrm{~cm}$ TL for males. Female fecundity was $4 \pm 1.8$ embryos $(\mathrm{n}=388)$. Length at birth was between 20 and $29 \mathrm{~cm}$ TL, and no differences in sex ratio were detected for embryos. Feeding analyses ( $\mathrm{n}=266$ stomachs) showed a diet mainly based on decapod crustaceans, small fish, stomatopods and cephalopods. The trophic level was 3.3, which shows feeding based on benthic and demersal species of the continental shelf, especially crustaceans.
\end{abstract}

Keywords: shark fishery; elasmobranch; Chondrichthyes; artisanal fishery; Caribbean.

Longitud de captura, reproducción y alimentación de la viuda amarilla, Mustelus higmani (Carcharhiniformes: Triakidae), en isla de Margarita, Venezuela

Resumen: Mustelus higmani está catalogada con "preocupación menor" en la lista roja de la IUCN, sin embargo existen vacíos de información sobre la tendencia poblacional en la mayoría de su rango de distribución. En Venezuela, esta especie tiene gran importancia local porque es parte de platos típicos tradicionales. El objetivo del presente trabajo es analizar la estructura poblacional, reproducción y alimentación de los ejemplares de M. higmani provenientes de los desembarques de la pesca artesanal de isla de Margarita, para contribuir con el manejo de la especie. Durante 2006-2008, fueron analizados 2223 ejemplares: 1156 hembras (24.8-88.4 cm LT) y 1067 machos $(20-69.2 \mathrm{~cm})$. Fueron detectadas variaciones temporales en la proporción sexual y estructura de longitudes. Una disminución de la longitud total y un incremento de organismos inmaduros fueron observados durante el 2008. La longitud media de madurez sexual $\left(\mathrm{L}_{50}\right)$ fue estimada en $46.7 \mathrm{~cm} \mathrm{LT}$ para las hembras y $47.6 \mathrm{~cm}$ LT para machos. La fecundidad uterina fue estimada en $4 \pm 1.8$ embriones $(\mathrm{n}=388)$. Longitud cercana al nacimiento entre 20-29 cm LT, sin diferencias en la proporción sexual de embriones. Los análisis de alimentación ( $\mathrm{n}=266$ estómagos) muestran una dieta basada principalmente en crustáceos decápodos, peces pequeños, estomatópodos y cefalópodos. El nivel trófico calculado fue 3.3. La especie muestra una alimentación basada en especies demersales y del bentos habitantes de la plataforma continental, especialmente crustáceos.

Palabras clave: Pesca de tiburones; elasmobranquios; condríctios; pesca artesanal; Caribe.

Citation/Como citar este artículo: Tagliafico A., Hernández-Ávila I., Rangel S., Rago N. 2015. Size of catch, reproduction and feeding of the small-eye smooth-hound, Mustelus higmani (Carcharhiniformes: Triakidae), in Margarita Island, Venezuela. Sci. Mar. 79(4): 443-452. doi: http://dx.doi.org/10.3989/scimar.04245.09A

Editor: P. Sartor.

Received: March 26, 2015. Accepted: July 10, 2015. Published: October 15, 2015.

Copyright: (c) 2015 CSIC. This is an open-access article distributed under the Creative Commons Attribution-Non Commercial Lisence (by-nc) Spain 3.0. 


\section{INTRODUCTION}

The vulnerability of sharks is well known and cases of overexploitation have been documented around the world (Musick et al. 2000, Castro 2013). However, sustainable shark fisheries have been achieved in British Columbia and Australia as a result of rigorous management programmes (Walker 1998). The baseline of these programmes requires information about the biology of the species, as well as trends in fisheries. Unfortunately, in the Caribbean the local agencies have at their disposal poor information about elasmobranch fisheries, sometimes with similar species merged in a single item, so management decisions are limited (Shing 1999, Tavares 2009, Rosa and Gadig 2010).

In Venezuela, one of the most important resources in artisanal shark fisheries is the small-eye smoothhound shark, Mustelus higmani Springer and Lowe 1963, locally known as "viuda amarilla". Between 1990 and 2006, shark landings in the northeastern region were $3000 \mathrm{t}^{-1}$, with $M$. higmani accounting for around $40 \%$ of this catch (Tavares et al. 2010). This species is also an important resource in other Caribbean countries and Brazil (Lessa et al. 1999, Shing 1999, 2006). In Venezuela, sharks and rays are highly appreciated because they are included in typical dishes (Cervigón and Alcalá, 1999). The increasing local demand and economic value cause high fishing pressure on this resource. Although M. higmani is categorized as "least concern" by the red list of the International Union for Conservation of Nature, this estimation is only based on data from Brazil. Information about fisheries and population features throughout the distributional range is necessary to evaluate the current conservation status of this species (Faria and Furtado 2006).

Studies of $M$. higmani are mainly restricted to general descriptions (Compagno 1984, Cervigón et al. 1992, Cervigón and Alcalá 1999, Compagno et al. 2005) and taxonomical revisions (Heemstra 1997, Rosa and Gadig 2010). However, Springer and Lowe (1963) and Tavares et al. (2010) provide useful biological information.

We studied the landings from the artisanal fishery of Margarita Island between January 2006 and December 2008 in order to generate baseline information regarding reproduction and feeding habits that may contribute to update the conservation status of $M$. higmani.

\section{MATERIALS AND METHODS}

\section{Area of study}

Margarita Island is located on the northeast coast

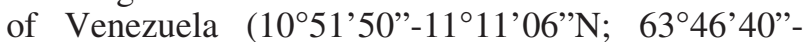
$64^{\circ} 24^{\prime} 32^{\prime \prime} \mathrm{W}$ ), in a seasonal upwelling coastal area of the Southern Caribbean (Fig. 1). The area sustains abundant marine resources, mainly small clupeids and bivalves, exploited by local artisanal fisheries (Freón and Mendoza 2003, Marcano et al. 2005). Particularly, the investigated fishery uses small wooden boats, with outboard engines. Shark catches were obtained using bottom monofilament gill nets of $0.45-0.5 \mathrm{~mm}$ thick-

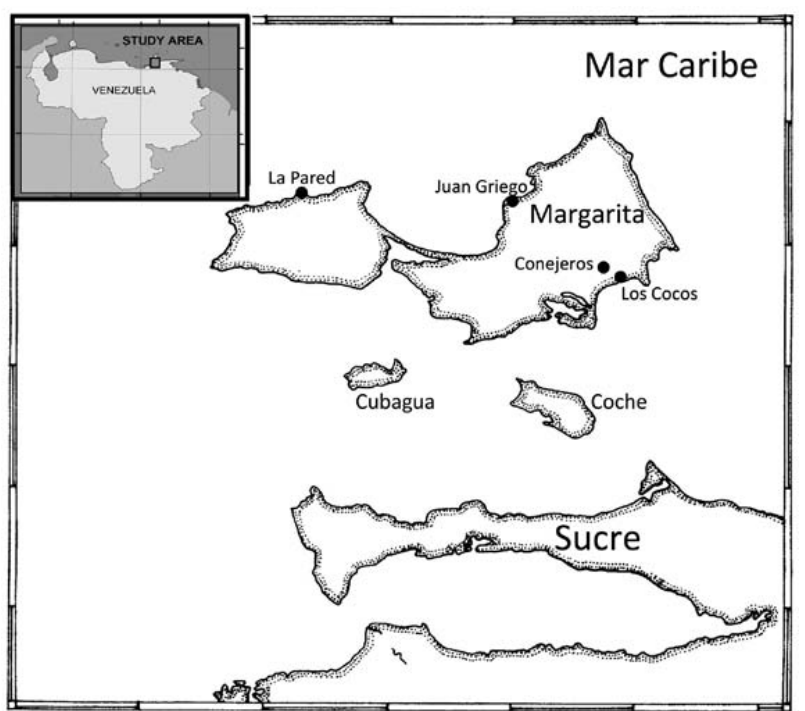

Fig. 1. - Study area and sampling sites

ness, 3-inch mesh size, a length of 100-1500 m and a height of 3-4 m. Usually the nets are deployed in the water from 4 to $6 \mathrm{pm}$ and collected the next morning from 5 to 8 am. Ginés et al. (1972), Iriarte (1997) and González et al. (2006) reported more details of fishing areas, gear and boats.

\section{Sampling methods}

Sampling was performed from January 2006 to December 2008 at two important fishing ports of Margarita Island (Juan Griego and La Pared), and also at two fish markets (Los Cocos and Conejeros) (Fig. 1). Each location was monitored once a week, on different days, between 7 and 9 am. Specimens were identified following the descriptions of Compagno (1984) and Cervigón and Alcalá (1999). Reference specimens were deposited in the fish collection of the Ichthyology Laboratory of Universidad de Oriente, Boca de Río, Venezuela.

Total length (TL) was measured (precision $1 \mathrm{~mm}$ ) following Cervigón and Alcalá (1999). Sex and reproductive stage were identified according to Stehmann (2002) and Conrath (2004). As processing and commercialization in this fishery is usually a very fast practice, it was not possible to collect more data on the landed specimens. However, clasper length and ova diameter were measured from a subsample for males and females, respectively. Embryos were counted, measured and sexed in order to estimate uterine fecundity, length at birth and embryo sex ratio.

Stomachs were dissected from a subsample of specimens $(n=266)$. Feeding items were identified to the lowest taxonomic level possible according to various keys and descriptions (Rodríguez 1980, Williams 1984, Abele and Kim 1986, Cervigón 1991, Melo 1999). Although food consumption estimations can be affected by the type of sampling gear used (Cortés 1997), the low ratio of empty stomachs and the good conditions of preys suggest that there were no effects caused by gillnets on feeding estimation. 


\section{Data analyses}

Total sex ratio and its variation through size classes (pooling extreme low-frequency classes) were analysed with a $\chi^{2}$ test and temporal variations in sex ratio of the catch were analysed using a $\chi^{2}$ test for heterogeneity. For this analysis, data were pooled in four-monthly periods, corresponding to early (January-April), middle (May-August) and late (September-December) periods of each year. Similarly, temporal variations of size class structure were analysed by measuring kurtosis, skewness and a normal distribution (Kruskal-Wallis test).

Temporal variation in the TL of the specimens landed was examined using a multifactorial analysis of variance (ANOVA). The ANOVA was performed to test the null hypothesis of non-differences in TL of captured specimens in relation to year and sex. Also, factors such as period (early, middle and late part of each year) and sampling dates (as a random factor nested in the period-sex combination) were included to avoid confusion with temporal variation scales. Although different dates also include different monitored ports or markets, the similar patterns between sites, the limited spatial coverage of the fisheries and the population distribution allows us to assume that the captures belong to the same general fishing ground. Criteria on statistical assumptions for this data analysis follow McGuinness (2002). Similarly, an ANOVA was performed to test the null hypothesis of non-differences existing in the ratio of immature specimens in catches by sex and year. Data were previously arcsine (x) transformed (Zar 1996). As in the previous analysis, period and sampling dates were included for control of different scales of temporal variation. In both cases, a t-test was performed as an a posteriori analysis.

Length at maturity was estimated for males and females. Observed data on size and maturity stage were analysed using the logistic function

$$
\mathrm{M}_{\mathrm{f}}=1 / 1+\mathrm{e}^{-\mathrm{a}\left(\mathrm{L}_{\mathrm{i}}-\mathrm{b}\right)}
$$

where $\mathrm{M}_{\mathrm{f}}$ is the fraction of mature individuals, $a$ is the change in slope of $\mathrm{M}_{\mathrm{f}}$ as a function of length intervals $\left(\mathrm{L}_{\mathrm{i}}\right)$, and $\mathrm{b}$ is the length at $50 \%$ maturity $\left(\mathrm{L}_{50}\right)$. Estimates of $\mathrm{a}$ and $\mathrm{b}$ were obtained by using the least squares method with $\mathrm{R}$ statistical software, version 2.13.0 (R Development Core Team 2011).

Ova diameter and clasper length were related to the $\mathrm{TL}$ of females and males, respectively, using correlation analysis. The relationship between the number of embryo and TL of females was adjusted to a potential model, following Holden and Raitt (1975).

In order to describe the feeding habits, an accumulative curve of items found in stomachs was performed to corroborate sampling effort sufficiency (Cortés 1997). The quantitative description of each food item in this study includes its proportion in number $(\% \mathrm{~N})$ and weight $(\% \mathrm{~W})$, its frequency of occurrence $(\% \mathrm{~F})$, the index of relative importance (IRI) and the percentage IRI (Cortés 1999). Trophic level was also estimated according to Cortés (1999).

\section{RESULTS}

\section{Population structure, body size and juvenile ratio}

A total of 2223 specimens were analysed. Total sex ratio was slightly in favour of females (1.1:1 female: male, $\left.\chi^{2}=4.060, \mathrm{p}=0.043\right)$. However, heterogeneity in sex ratio was detected between periods $\left(\chi^{2}=281.36\right.$, $\mathrm{p}<0.001)$. For instance, in mid-2006 and mid-2007, more males were found $\left(1: 2.31, \chi^{2}=71.36, \mathrm{p}<0.001\right.$; $1: 1.45, \quad \chi^{2}=11.50, \quad \mathrm{p}<0.001$, respectively), whereas in late 2006 and early 2007 more females were found $\left(1.68: 1, \chi^{2}=17.56, \mathrm{p}<0.001 ; 4.60: 1, \chi^{2}=181.61\right.$, $\mathrm{p}<0.001$, respectively). Other periods showed no significant differences $\left(\chi^{2}, p>0.05\right)$. Sex ratio showed variations related to body size. Size classes below 47.5 $\mathrm{cm}$ TL (composed mainly of juveniles) showed no differences in sex ratio from $1: 1\left(\chi^{2}, p>0.05\right)$, while males dominated in the range between 47.5 and $52.4 \mathrm{~cm}$ TL, and females dominated over $57.5 \mathrm{~cm}$ TL $\left(\chi^{2}, \mathrm{p}<0.05\right.$ for all cases). No differences were observed in the sex ratio of embryos $\left(\chi^{2}=0.046, p=0.83\right)$.

Size range was between 24.8 and $88.4 \mathrm{~cm}$ TL for females and between 20 and $69.2 \mathrm{~cm}$ for males. Temporal variations were detected for length class structure (Fig. 2). Most periods showed a unimodal distribution, with aggregations into few length classes, except mid-2007 and early 2008, when a slight bimodal distribution was observed. Moreover, frequencies were biased to larger sizes in 2006-2007, whereas in 2008 more frequencies occurred in lower length classes. This trend was also found in modal class variation during the study. In 20062007, modal classes were between 47.5 and $62.4 \mathrm{~cm}$ TL. By contrast, a bimodal structure was found in early 2008 , split into small and large sizes. Size class between 42.5 and $47.4 \mathrm{~cm}$ TL dominated the unimodal distributions during the remaining periods of 2008 (Fig. 2).

According to the results of the ANOVA test, variations in body size were dependent on the combination of sex, period and year (Table 1). Although females were larger than males, temporal variations of males and females size showed a similar trend throughout the years. In 2006-2007, females showed slight variations in TL (2006: $52.46 \pm 7.13 \mathrm{~cm}$, mean \pm standard deviation; 2007: $54.12 \pm 8.61 \mathrm{~cm})$, but a decrease was detected in $2008(46.89 \pm 6.74 \mathrm{~cm})$. Similarly, males showed no differences in TL in 2006-2007 (49.29 \pm 3.43 and $49.63 \pm 6.76 \mathrm{~cm}$, respectively) but showed a decrease in $2008(47.01 \pm 5.32 \mathrm{~cm})$. For both sexes a decrease in TL in 2008 in relation to previous years was significant (t-test, $\mathrm{P}<0.001$ in all combinations). The a posteriori analysis by periods showed similar trends, with emphasis in size reduction in mid- and late 2008.

The ANOVA test related to juvenile proportion of the catches was consistent with the observed body size changes. Although catches showed no differences in juvenile proportion related to sex, temporal differences were detected. Juvenile proportion changed according to year and period combination (Table 1). In 20062007, juvenile proportion was $23 \%$, but in 2008 it increased to $54 \%$ (t-test, $\mathrm{P}<0.001$ ), particularly due to a high capture of juveniles in mid- and late 2008. The 

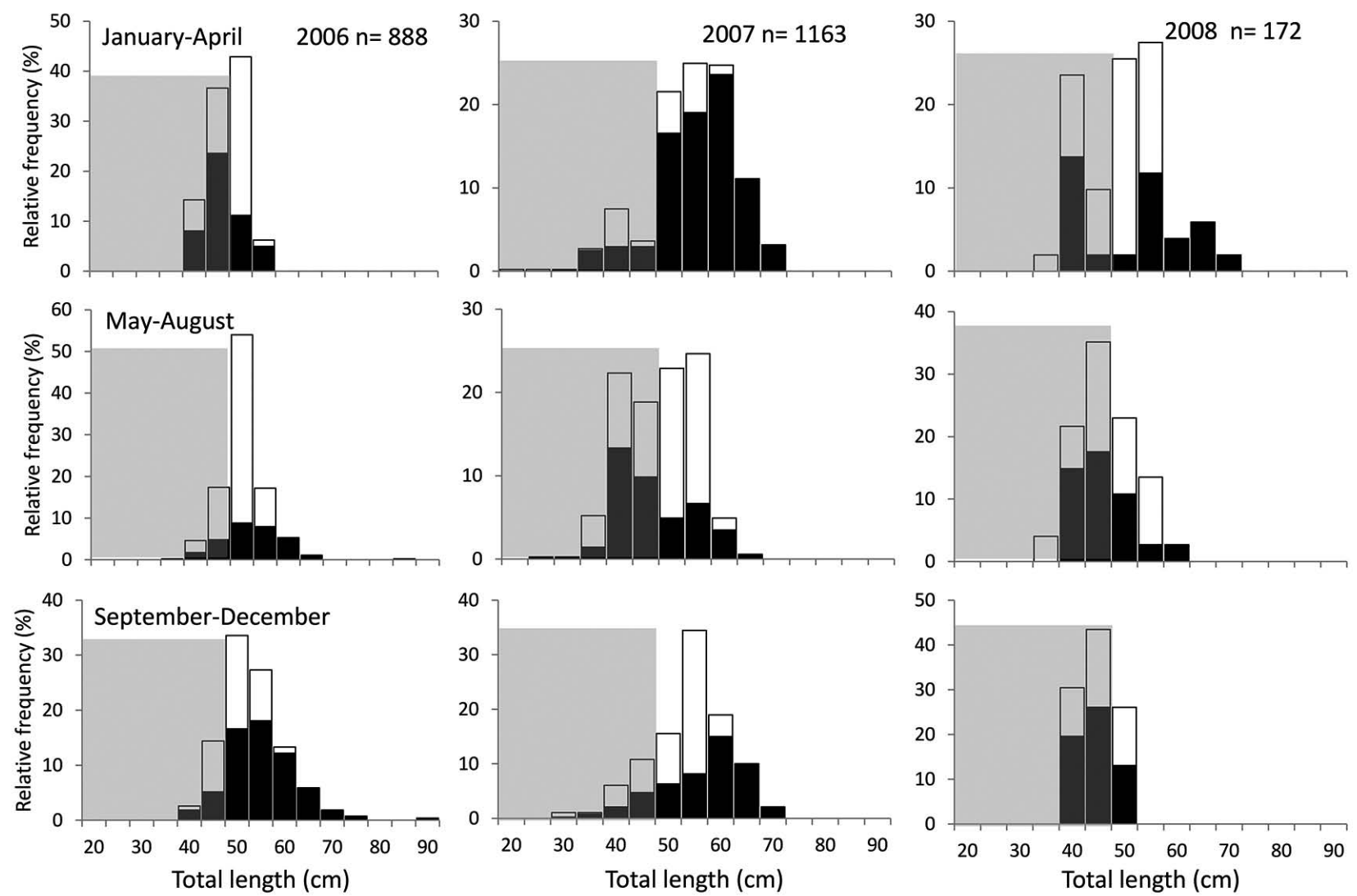

Fig. 2. - Length structure of Mustelus higmani captured by the artisanal fishery of Margarita Island, Venezuela in 2006-2008. Shaded area indicates immature individuals: black bars, females; white bars, males.

Table 1. - ANOVA test of variation in body size and juvenile proportion in the catch of Mustelus higmani captured by the artisanal fishery of Margarita Island, Venezuela, from 2006-2008. Bold denotes significant differences, \%Var: variation associated at each level.

\begin{tabular}{|c|c|c|c|c|c|c|c|c|}
\hline \multirow[b]{2}{*}{ Source } & \multicolumn{4}{|c|}{ Body size } & \multicolumn{4}{|c|}{ Juvenile proportion } \\
\hline & $\mathrm{df}$ & $\mathrm{F}$ & $\mathrm{p}$ & $\%$ Var & df & $\mathrm{F}$ & $\mathrm{p}$ & $\%$ Var \\
\hline Year [Y] & 2 & 30.031 & $<0.001$ & 4.15 & 2 & 8.220 & 0.002 & 18.30 \\
\hline $\operatorname{Sex}[S]$ & 1 & 4.994 & 0.036 & 2.74 & 1 & 1.636 & 0.215 & 1.89 \\
\hline Period $[\mathrm{P}]$ & 2 & 2.219 & 0.134 & 1.25 & 2 & 0.260 & 0.773 & 0.00 \\
\hline $\mathrm{Y} \times \mathrm{S}$ & 2 & 6.360 & 0.002 & 1.53 & 2 & 1.299 & 0.293 & 1.52 \\
\hline $\mathrm{Y} \times \mathrm{P}$ & 4 & 23.347 & $<0.001$ & 9.25 & 4 & 2.991 & 0.041 & 13.73 \\
\hline $\mathrm{S} \times \mathrm{P}$ & 2 & 1.238 & 0.310 & 0.49 & 2 & 1.093 & 0.354 & 0.81 \\
\hline Dates $(\mathrm{S} \times \mathrm{P})$ & 18 & 9.161 & $<0.001$ & 6.62 & 18 & 2.010 & 0.060 & 16.34 \\
\hline $\mathrm{Y} \times \mathrm{S} \times \mathrm{P}$ & 4 & 14.612 & $<0.001$ & 11.27 & 4 & 1.832 & 0.159 & 11.48 \\
\hline Res & 2190 & & & 62.70 & 22 & & & 35.95 \\
\hline Total & 2225 & & & & 57 & & & \\
\hline
\end{tabular}

previous results suggest that catches switched from relatively large and mostly mature specimens in 20062007 to small ones in 2008 , mostly immature.

\section{Sexual maturity and reproductive period}

The minimum size of gravid and post-gravid females was 41.7 and $49 \mathrm{~cm}$ TL, respectively. For males, the minimum size at maturity was observed at $39.8 \mathrm{~cm}$ TL. The average size at which $50 \%$ of females were mature $\left(\mathrm{L}_{50}\right)$ was estimated at $46.7 \mathrm{TL} \mathrm{cm}$ for females; confidence intervals $(95 \%)$ for this parameter ranged between 45.2 and $48.0 \mathrm{~cm}$, between 0.2 and 0.4 for the slope. For males, $\mathrm{L}_{50}$ was estimated at $47.6 \mathrm{~cm}$ TL, with confidence intervals between 47.0 and $48.1 \mathrm{~cm}$, and between 0.3 and 0.4 for the slope. Slope estimations were 0.339 and 0.32 for males and females, respectively.
Mature males and females were observed practically throughout the sampling period. Similarly, gravid females with embryos in different stages of development were observed in almost all samples, with no evident temporal pattern. These findings suggest a continuous reproduction for the species (Figs 3, 4). Moreover, larger ova were observed in both gravid and post-gravid females, denoting that ovum and embryo development can occur simultaneously. All males greater than $55 \mathrm{~cm}$ TL and with a clasper length greater than $4 \mathrm{~cm}$ were mature (Fig. 5).

\section{Fecundity and embryo length}

From the 388 embryos analysed, the maximum observed body size was $29 \mathrm{~cm}$ TL. Since the minimum size for the juveniles caught was $20 \mathrm{~cm}$ TL, these results 


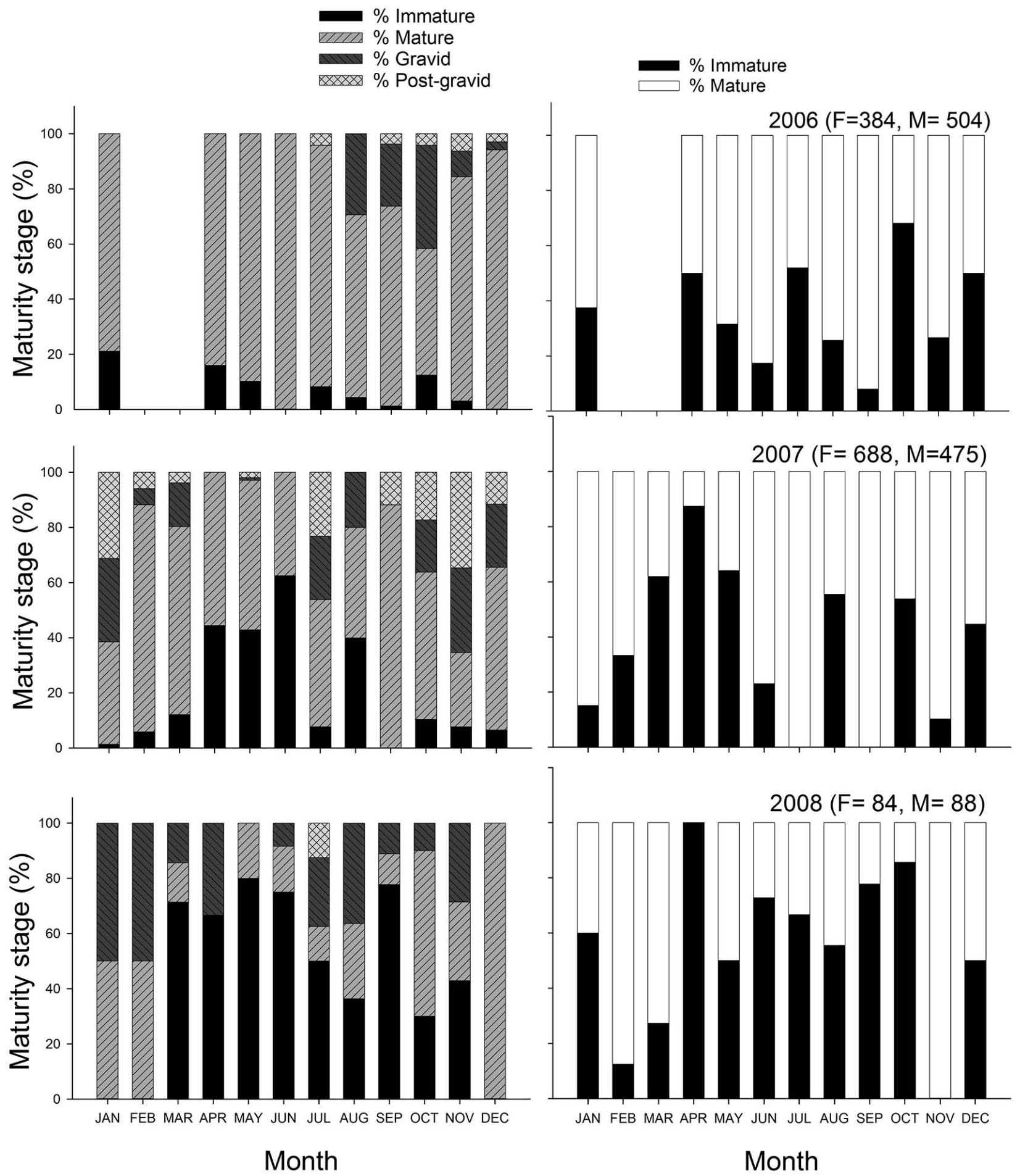

Fig. 3. - Maturity stages of females (left) and males (right) of Mustelus higmani captured by the artisanal fishery of Margarita Island, Venezuela, from 2006 to 2008 .

suggest a length at birth ranging between 20 and $29 \mathrm{~cm}$ TL. Large embryos were observed in different periods, particularly in October 2006, March-May 2007, October-November 2007, January-March 2008 and August 2008 (Fig. 4). Both ovum diameter $(\mathrm{r}=0.825, \mathrm{p}<0.001$, $\mathrm{n}=101)$ and clasper length $(\mathrm{r}=0.786, \mathrm{p}<0.001, \mathrm{n}=384)$ were positively correlated with body size of females and males, respectively. A maximum fecundity of 10 embryos was found in a female of $69 \mathrm{~cm}$ TL; however, the average fecundity was $4 \pm 1.8$ embryos. A positive correlation between TL of females and number of embryos was detected $\left(\mathrm{F}_{18.9281}, \mathrm{r}=0.480, \mathrm{p}<0.001\right)$.

\section{Feeding}

Only $13 \%$ of dissected stomachs $(n=266)$ were empty and they were not included in the posterior analysis. The cumulative curve of prey reached an as- 


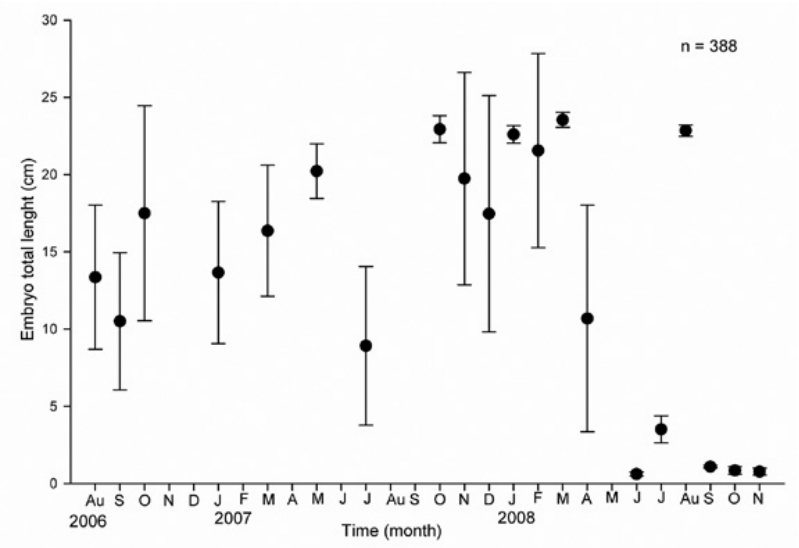

Fig. 4. - Average length (centre point) and standard deviation (error bars) of Mustelus higmani embryos captured by the artisanal fishery of Margarita Island, Venezuela from 2006 to 2008.
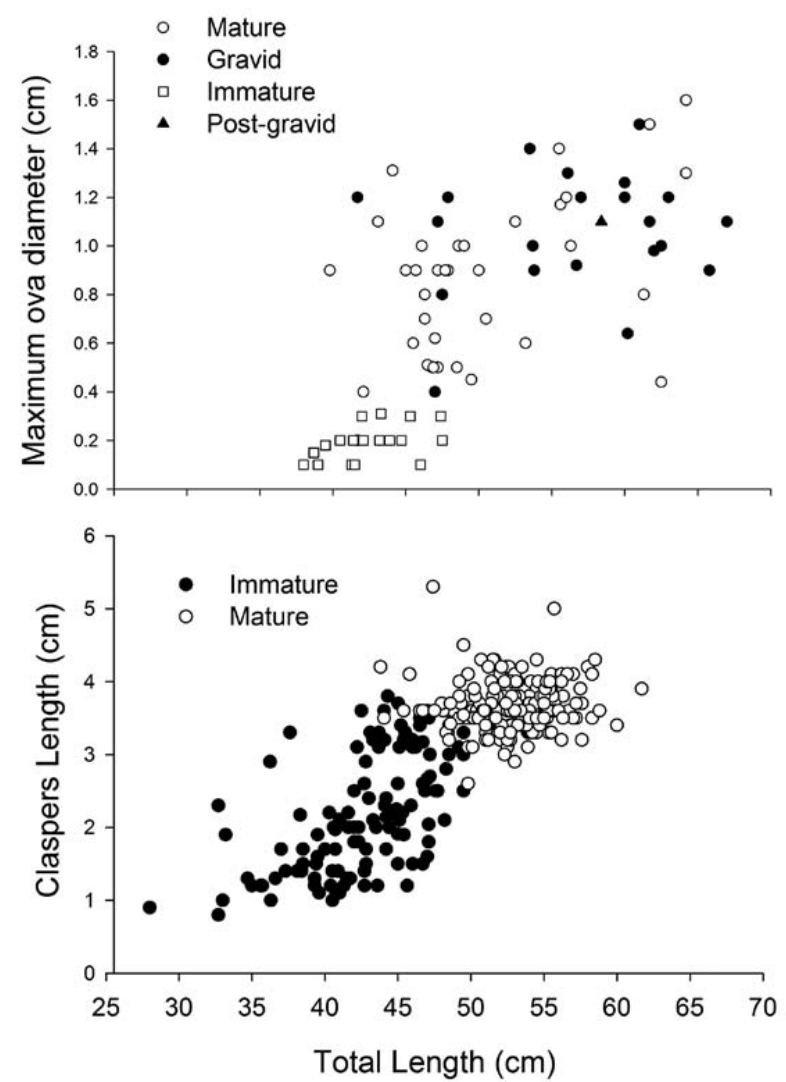

Fig. 5. - Maximum ovum diameter of females at different maturity stages (top) and male clasper length vs. total length (bottom), of Mustelus higmani captured by the artisanal fishery of Margarita Island, Venezuela from 2006 to 2008.

ymptotic trend after 200 stomachs had been analysed. At least 40 different taxa (species to family level) of consumed prey were detected, within 15 major taxa (Table 2).

The relative importance index showed that decapod crustaceans are the most important item consumed by $M$. higmani. Decapods dominate in abundance, weight and frequency, showing relative importance in highest scores. They were followed in relative importance by fish, stomatopods and cephalopods. Secondary food items were gastropods, polychaetes, octocorals, seaweed, and remains of Thalassia (Table 2). Similar scores were obtained by comparing the stomach contents between juveniles and adults. However, small differences were found, such as a higher consumption of fishes $(\% \mathrm{IRI}=4.5)$ in juveniles than adults $(\% \mathrm{IRI}=2.5)$. Moreover, secondary food items were less frequent in adults.

Most of the identified crustaceans are species that inhabit sandy environments (the families Calappidae, Portunidae, Partenopidae, Speocarcinidae, and Euryplacidae) and also infaunal species (the families Upogebiidae, Ctenochelidae, and Stomatopoda) (Table 2). All hermit crabs (Paguridae and Diogenidae) were found without shells, and a large proportion of the preys were found complete (even intact) in the stomachs. Finally, the overall trophic level of the species was estimated at 3.3. Differences in trophic level were not detected between sexes or stages of maturity.

\section{DISCUSSION}

Fishery managers should consider the temporal decrease in size and the increase in proportion of juveniles as symptoms of overexploitation of the stocks concerned, which therefore need specific monitoring plans. Powers et al. (2013) found a decrease in elasmobranch length in the Gulf of Mexico since 1980, associated with fisheries. Although the relative decrease in size in the present study is still low and the sampling period (three years) is not enough to detect robust trends, its combination with increases in the proportion of juveniles (up to $50 \%$ of the catches in 2008), could suggest a tendency towards the occurrence of suboptimal conditions for the fishery with the passing of time. Similar results with larger proportions of immature organisms in the catches were also observed by Tavares et al. (2010) in the same region and are also observed in other elasmobranchs caught by artisanal fisheries of Venezuela (Tavares 2009, Tagliafico et al. 2012, 2013).

Females of Mustelus higmani attain greater size than males (Compagno 1984, Cervigón and Alcalá 1999, Compagno et al. 2005), a common aspect for different species of the genus Mustelus, such as $M$. canis, M. norrisi (Cervigón and Alcalá 1999), M. antarcticus, $M$. griseus, M. lenticulatus, M. lunulatus, $M$. manazo, M. mustelus (Compagno et al. 2005) and $M$. punctulatus (Saidi et al. 2009). The largest body sizes previously reported for $M$. higmani were $75 \mathrm{~cm}$ and 59 $\mathrm{cm}$ TL for females and males, respectively (Tavares et al. 2010). The present work therefore reports a new maximum length, of $88.4 \mathrm{~cm}$ TL for females and 69.2 cm TL for males.

Temporal differences in population sex ratio suggest a low-scale spatial-temporal segregation. Springer and Lowe (1963) found an equal sex ratio in embryos, but reported the occurrence of some catches with just one sex. In the present study, occasional captures of a single sex (males o females) or combinations of adult females with young males were observed. Unfortunately, the lack of a defined pattern and the occurrence of 


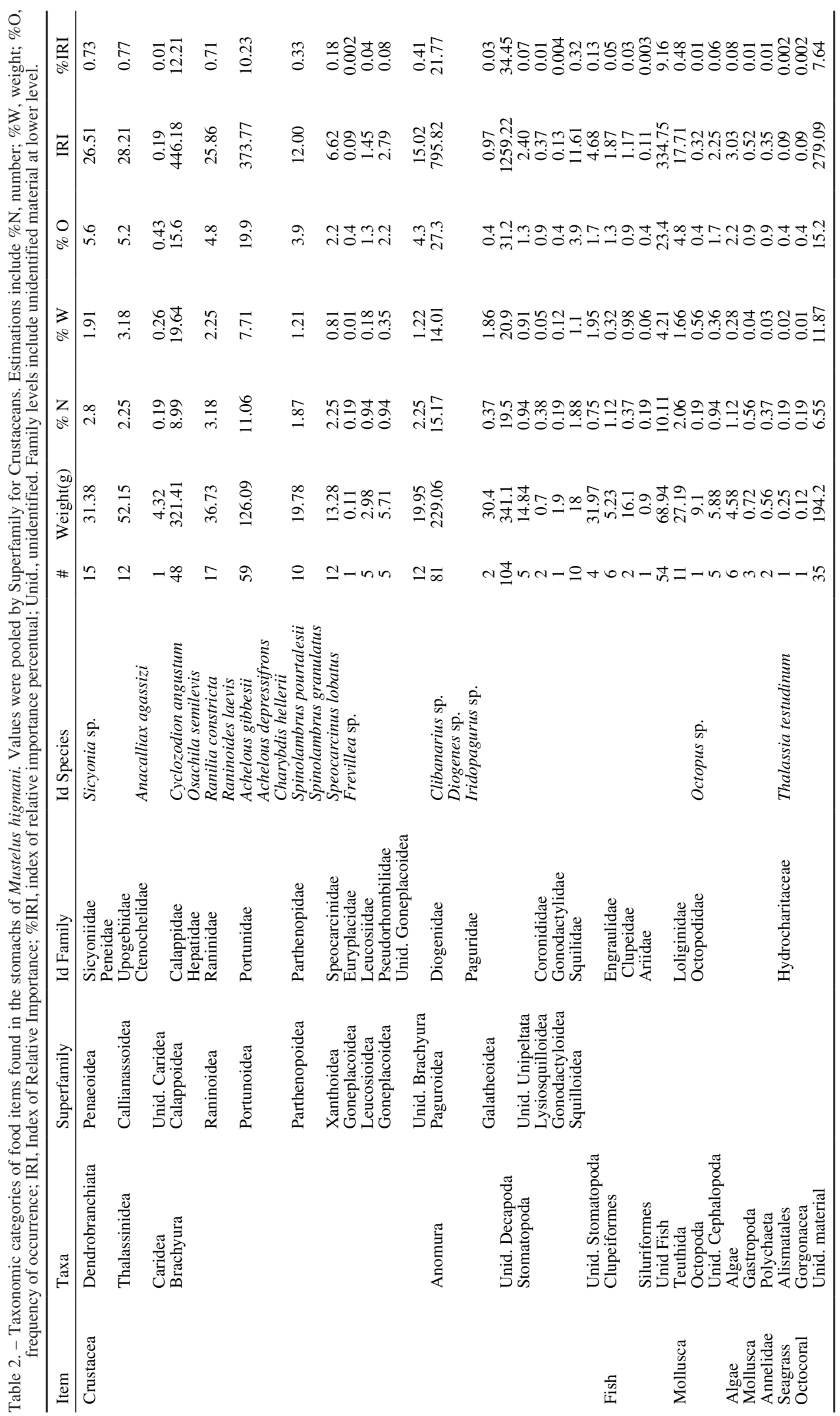


mixed groups preclude testing the sexual segregation hypothesis. Saidi et al. (2008) reported similar results for M. mustelus, with a similar sex ratio for embryos and variation for adults.

Springer and Lowe (1963) report a length at maturity of about 47.5 and $42.5 \mathrm{~cm}$ TL for females and males, respectively. Tavares et al. (2010) reports a mean length at maturity of $59.9 \mathrm{~cm}$ TL for females and $52.5 \mathrm{~cm}$ TL for males. In contrast, we found a lower mean length at maturity $(\mathrm{F}=46.7 \mathrm{~cm}$ TL; $\mathrm{M}=47.6 \mathrm{~cm}$ TL). These differences can be attributed to different sample sizes and sampling periods. In general, for other species of the genus Mustelus, males mature before females, although some exceptions have been reported (Rojas 2006).

Occurrence of gravid and post-gravid females during the 26 months of the study, jointly with the occurrence of embryos in different stages of development, seems to show that $M$. higmani reproduce continually throughout the year. Springer and Lowe (1963) reported similar results by analysing 123 females, of which 106 were pregnant without any temporal pattern, with different embryo sizes. Similar records of pregnant females throughout the year were made for M. manazo in Japan (Yamaguchi et al. 2000), suggesting a non-fixed reproductive period similar to that of many tropical species, possibly due to the narrow seasonal variation of the environment.

The large ovum diameter observed for gravid and post-gravid females suggests that they could be ready to copulate and become gravid again after giving birth. A similar pattern has been reported for M. manazo, since females can become pregnant four to six weeks after giving birth (Yamaguchi et al. 2000).

Gestation period for other species of this genus is 10 months (M. griseus, $M$. canis and $M$. manazo), 11 months (M. antarcticus, M. lenticulatus and $M$. muste$l u s$ ) and around one year (for M. asterias) (Compagno et al. 2005). In the present work, the continuous reproduction observed, with embryos that can be born at any time throughout the year, prevents us from estimating an accurate gestation period.

Female sharks commonly give birth near to the coast in order to raise survival probabilities of their offspring (Knip et al. 2010). This behaviour could explain the incidence of gravid females in the catches, as this artisanal fishery operates mainly in-shore. Gallucci et al. (2006) indicated that in these fisheries the risk of collapse of shark stocks increases because a large reproductive fraction of the population is captured annually. According to the current data, the risk could be even higher because catches also include a large proportion of juveniles.

A maximum fecundity of up to 10 embryos was suggested. However, this condition must be considered as rare, since it was observed in only one female, and pregnant females with more than seven embryos accounted for less than the $10 \%$ of gravid females. An average number of four embryos per female is similar to previous observations (Springer and Lowe 1963).

The smallest specimen observed in the landings (20 $\mathrm{cm}$ TL) was smaller than the largest embryo $(29 \mathrm{~cm})$, showing that first size of capture is similar to length at birth, due to the small mesh size of the net used, which makes it possible to catch all the available sizes. Also, some "early birth" of neonates, caused by the stress suffered by pregnant females caught by the nets, could be occurring. Springer and Lowe (1963) reported similar findings, with a catch of a neonate $(21.3 \mathrm{~cm}$ TL) smaller than the largest recorded embryo ( $24 \mathrm{~cm} \mathrm{TL})$. This observation of neonate catches is also reported in shark fisheries from Africa and the Mediterranean Sea (Kroese and Sauer 1998, Saidi et al. 2008).

A similar length at birth has been reported for this species (25 cm TL) (Tavares et al. 2010). For other species of the genus Mustelus, the size between 19 and $21 \mathrm{~cm}$ TL has been indicated (M. dorsalis, M. minicanis and $M$. henlei). However, lengths above $30 \mathrm{~cm}$ TL have been observed for other species (M. antarcticus, M. asterias, M. canis, M. fasciatus, M. lunulatus, $M$. manazo, M. mento, M. mustelus, $M$. punctulatus and $M$. sinusmexicanus) (Compagno et al. 2005).

The previous data on the diet of $M$. higmani (Springer and Lowe 1963) report a similar picture to that identified in the present work. M. higmani's food spectrum is based mainly on decapod crustaceans and stomatopods. Similarly, M. lunulatus, M. henlei, $M$. dorsalis, M. punctulatus, M. manazo and M. schmitti have a diet based on crustaceans (Yamaguchi and Tanuichi 2000, Gómez et al. 2003, Navia et al. 2006, Rojas 2006, Jardas et al. 2007, Saidi et al. 2009, Belleggia et al. 2012).

The large number of identified food items and the variation observed between different specimens suggests that $M$. higmani is an opportunistic nekto-benthic predator. Wetherbee et al. (1990) have indicated that in some elasmobranch species the stomach content varies according to environmental aspects and the abundance of preys. The identified preys suggest that this species consumes both benthic (epifaunal and infaunal species) and nekto-benthic preys, all commonly found on sandy bottoms of the continental shelf. Knip et al. (2010) suggests that small sharks frequently visit coastal zones to obtain prey in order to facilitate fast growth and quickly reach maturity length.

Crustaceans dominated the diet, but a considerable number of small clupeids (anchovies and sardines) that were identified could explain the low values in total weight of fishes. Also, some large remains of fish (possibly of the family Ariidae) were observed, suggesting that occasional large preys are trapped by some type of group hunt behaviour or scavenger feeding. Saidi et al. (2009) suggested the need for further research to corroborate the hypothesis of scavenger feeding for larger fish and to document ontogenic changes in the diet of M. punctulatus to consuming larger preys (like fish and molluscs) at greater sizes.

Trophic level decreases have been used to address overexploitation of resources in marine food webs (Pauly et al. 1998, Myers et al. 2007). Cortés (1999) estimated a trophic level for M. higmani of 3.6, which is slightly higher than the present estimation (3.3). This variation could be attributed to the presence of new rare items (algae, seagrass, octocorals, gastropods and 
polychaetes) possibly consumed by accident. Together, these food items represent less than $2 \%$ of the diet and could be considered trace food. For this reason, a new estimation of the trophic level was performed without including these items, resulting in the same trophic level reported by Cortés (1999). However, polychaetes, gastropods and vegetables have been previously reported as a common diet of this genus (Gómez et al. 2003, Jardas et al. 2007, Yamaguchi and Tanuichi 2000, Saidi et al. 2009, Belleggia et al. 2012), as well as echinoderms, bivalves and tunicates (Saidi et al. 2009).

There are noteworthy aspects of some observed food items. All hermit crabs (Paguridae and Diogenidae) were found without shells. Additionally, other consumed species inhabit galleries within sandy bottoms (thalassinideans and stomatopods) or hide themselves in sand (e.g. Calappidae and Parthenopidae crabs). Also, a large proportion of the preys were found complete (even intact) in the stomachs, and very few bite marks were observed. Based on these observations, we suggest that the species uses a suction mechanism to consume preys in sandy environments.

Other important findings about the diet of $M$. higmani are that it also includes the Indo-Pacific invasive species Charybdis hellerii. This portunid crab was observed in Venezuela in 1993 (Bolaños et al. 1997), and its distribution in the Atlantic includes Florida, the Caribbean Sea and Brazil (Campos and Türkey 1989, Lemaitre 1995, Mantelatto and Dias 1999). Along its distribution range in the Atlantic, $C$. hellerii is considered well established, forming dense populations on sandy habitats of both marine and estuarine coast (Bolaños et al. 2012, Sant'Anna et al. 2012). The occurrence of $C$. hellerii in the diet of $M$. higmani denotes that this species could play an important role as a natural predator of this invasive species.

Since $M$. higmani inhabits sandy environments of the continental platform, the current ban of the Venezuelan industrial trawl fishery (since 2009) could represent a sort of protection for its stocks. However, there is still a lack of other legal management measures to regulate the fishery of this important resource. Elevated proportions of immature specimens and gravid females in catches could represent a threat to the sustainable exploitation of the species. Most of the Venezuelan marine resources are currently recognized to be in a state of overfishing (Mendoza 2015), and several elasmobranch fisheries have already shown a lack of precautionary management. The occurrence of high percentages of immature individuals and pregnant females in elasmobranch catches (Tavares 2009, Tagliafico et al. 2012, 2013) must be avoided in order to preserve these valuable resources.

We therefore recommend the implementation of a continuous monitoring plan for the fishery targeting this species, aimed at obtaining useful information to properly manage this resource.

\section{ACKNOWLEDGEMENTS}

To the fishermen and fish retailers for their kind cooperation. To INIA and A. Lárez for the logistic help.
C. Romero, V. Biermeyer, the anonymous referees and the editor provided valuable comments to improve the manuscript.

\section{REFERENCES}

Abele L., Kim W. 1986. An illustrated guide to the marine decapod crustaceans of Florida. Department of Environmental Regulation, Florida, $760 \mathrm{pp}$.

Belleggia M., Figueroa D., Sánchez F., et al. 2012. The feeding ecology of Mustelus schmitti in the southwestern Atlantic: geographic variations and dietary shifts. Environ. Biol. Fish. 95: 99-114. http://dx.doi.org/10.1007/s10641-011-9874-3

Bolaños J.A., Hernández G., Hernández J.E., et al. 1997. Presencia de Charybdis helleri (Crustacea: Decapoda: Portunidae) en aguas marinas de Venezuela. Avicenia 6/7: 147-148.

Bolaños J.A., Baeza J.A., Hernández J.E., et al. 2012. Population dynamics and reproductive output of the non-indigenous crab Charybdis hellerii in the southeastern Caribbean Sea. J. Mar. Biol. Assoc. U.K. 92(3): 469-474. http://dx.doi.org/10.1017/S002531541100052X

Campos N.H., Turkay M. 1989. On a record of Charybdis helleri from the Caribbean coast of Colombia. Senckenb. Marit. 20: $119-123$.

Castro J.I. 2013. Historical knowledge of sharks: ancient science, earliest American encounters, and American science, fisheries, and utilization. Mar. Fish. Rev. 75 (4): 1-26. http://dx.doi.org/10.7755/MFR.75.4.1

Cervigón F. 1991. Los peces marinos de Venezuela. Vol I, Fundación Científica Los Roques, Caracas, 425 pp.

Cervigón F., Alcalá A. 1999. Los peces marinos de Venezuela. Vol. 5, Fundación Museo del Mar, Caracas, $231 \mathrm{pp}$.

Cervigón F., Cipriani R., Fisher W., et al. 1992. Guía de campo de las especies comerciales marinas y de aguas salobres de la costa septentrional de Sur América. Fichas FAO de identificación de especies para la pesca, Roma, $513 \mathrm{pp}$.

Compagno L.J.V. 1984. FAO species catalogue. Vol. 4. Sharks of the world. An annotated and illustrated catalogue of shark species known to date. Vol. 4, Carcharhiniformes, FAO Fish. Synop, Roma, 655 pp.

Compagno L., Dando M., Fowler S. 2005. Sharks of the world, Princeton Field Guides. Princeton University Press, NJ. 368 pp.

Conrath C. 2004. Reproductive biology. In: Musick J., Bonfil R. (eds), Elasmobranch fisheries management techniques. APEC secretariat, Singapore, pp. 133-164.

Cortés E. 1997. A critical review of methods of studying fish feeding based on analysis of stomach contents: application to elasmobranch fishes. Can. J. Fish. Aquat. Sci. 54: 726-737. http://dx.doi.org/10.1139/f96-316

Cortés E. 1999. Standardized diet compositions and trophic levels of sharks. ICES J. Mar. Sci. 56:707-717. http://dx.doi.org/10.1006/jmsc.1999.0489

Faria V., Furtado M. 2006. Mustelus higmani. IUCN Red List of Threatened Species. Version 2014.3. Available from www. iucnredlist.org, accessed March 2015.

Freón P., Mendoza J. 2003. La sardina (Sardinella aurita) su medio ambiente y explotación en el oriente de Venezuela. Institut de Reserche pour le Development, Collection Colloques et Seminaries, Paris, 549 pp.

Gallucci V., Taylor I., Erzini K. 2006. Conservation and management of exploited shark population base don reproductive value. Can. J. Fish. Aquat. Sci. 63: 931-942. http://dx.doi.org/10.1139/f05-267

Ginés H., Angell C., Méndez M., et al. 1972. Carta pesquera de Venezuela. Áreas del nororiente y Guayana. Fundación La Salle de Ciencias Naturales, Caracas, 327 pp.

Gómez G., Zapata L.A., Franke R., et al. 2003. Hábitos alimentarios de Mustelus lunulatus y M. henlei (Pisces: Triakidae) colectados en el Parque Natural Gorgona, Pacífico colombiano. Bol. Inv. Mar. Cost. 32: 219-231.

González L.W., Eslava N. Guevara F. 2006. Catálogo de la pesca artesanal del Estado Nueva Esparta, Venezuela. Instituto de Investigaciones Científicas, Universidad de Oriente, Cumaná. $222 \mathrm{pp}$.

Heemstra P.C. 1997. Review of the Smooth-hound sharks genus Mustelus, Family Triakidae of the Western Atlantic Ocean, with descriptions of two new species and a new sub-species. Bull. 
Mar. Sci. 60: 894-928.

Holden M., Raitt. D. 1975. Manual de ciencia pesquera. Parte 2. Métodos para investigar los recursos pesqueros y su aplicación. Doc. Téc. FAO. Pesc. Roma, 1211 pp.

Iriarte L. 1997. Embarcaciones, artes y métodos de pesca del estado Nueva Esparta. Fundación La Salle de Ciencias Naturales, Caracas, $349 \mathrm{pp}$.

Jardas I., Santic M., Nerlovic V., et al. 2007. Diet composition of blackspotted smooth-hound, Mustelus punctulatus (Risso, 1826), in the eastern Adriatic Sea. J. Appl. Ichthyol. 23: $279-281$. http://dx.doi.org/10.1111/j.1439-0426.2006.00826.x

Knip D., Heupel M., Simpfendorfer C. 2010. Sharks in nearshore environments: models, importance, and consequences. Mar. Ecol. Prog. Ser. 402: 1-11. http://dx.doi.org/10.3354/meps08498

Kroese M., Sauer W. 1998. Elasmobranch exploitation in Africa. Mar. Freshw. Res. 49: 573-577 http://dx.doi.org/10.1071/MF97122

Lemaitre R. 1995. Charybdis hellerii (Milne Edwards, 1867), a nonindigenous portunid crab (Crustacea: Decapoda: Brachyura) discovered in the Indian River lagoon system of Florida. Proc. Bio. Soc. Wash. 108: 643-648.

Lessa R., Santana F., Rincón G., et al. 1999. Biodiversidade de elasmobranquios do Brasil. Ministerio do Meio Ambiente, Recife, $154 \mathrm{pp}$.

Mantelatto F.L., Dias L.L. 1999. Extension of the known distribution of Charybdis hellerii (A. Milne Edwards, 1867) (Decapoda, Portunidae) along the western tropical south Atlantic. Crustaceana 72: 617-620.

Marcano J., Prieto A., Lárez A., et al. 2005. Crecimiento y mortalidad de Pinctada imbricata (Mollusca: Pteridae) en Guamachito, Península de Araya, Estado Sucre, Venezuela. Cs. Mar. 31: 387-397.

McGuinness K.A. 2002. Of rowing boats, ocean liners and tests of the ANOVA homogeneity of variance assumption. Aust. Ecol. 27: $681-688$. http://dx.doi.org/10.1046/j.1442-9993.2002.01233.x

Melo G. 1999. Manual de identificacao dos Crustacea Decapoda do litoral Brasileiro: Anomura, Thalassinidea, Palinuridea, Astacidea. Editora Pleidade, São Paulo, 551 pp.

Mendoza J. 2015. Rise and fall of Venezuelan industrial and artisanal marine fisheries: 1950-2010. Fisheries Centre, The University of British Columbia, Working Paper Series, N²7, 16 pp.

Musick J.A., Burgess G., Cailliet G., et al. 2000. Management of sharks and their relatives (Elasmobranchii). Fisheries 25(3): 9-13.

http://dx.doi.org/10.1577/1548-8446(2000)025<0009:MOSAT $\mathrm{R}>2.0 . \mathrm{CO} ; 2$

Myers R., Baum J., Shepherd T., et al. 2007. Cascading effects of the loss of apex predatory sharks from a coastal ocean. Science 315:1846-1850. http://dx.doi.org/10.1126/science.1138657

Navia A., Giraldo A., Mejía-Falla P. 2006. Notas sobre la biología y dieta del toyo vieja (Mustelus lunnulatus) en la zona central de pesca del Pacífico colombiano. Invest. Mar. Valparaiso. 34: 217-222.

Pauly D., Christensen V., Dalsgaard J., et al. 1998. Fishing Down Marine Food Webs. Science 279: 860-863 http://dx.doi.org/10.1126/science. 279.5352.860

Powers S., Fodrie J., Scyphers S., et al. 2013. Gulf-wide decreases in the size of large coastal sharks documented by generations of fishermen. Mar. Coast. Fish. 5: 93-102. http://dx.doi.org/10.1080/19425120.2013.786001

R Development Core Team. 2011. R: A language and environment for statistical computing. R Foundation for Statistical Computing, Vienna, Austria. Available from http://www.r-project.org/. Accessed September 2014.

Rodríguez G. 1980. Los Crustáceos decápodos de Venezuela. Instituto Venezolano de Investigaciones Científicas, Caracas, 494 pp.

Rojas J.R. 2006. Reproducción y alimentación del tiburón enano Mustelus dorsalis (Pisces: Triakidae) en el golfo de Nicoya, Costa Rica: elementos para un manejo sostenible. Rev. Biol. Trop. 54: 861-871. http://dx.doi.org/10.15517/rbt.v54i3.13683

Rosa M., Gadig O. 2010. Taxonomic comments and an identification key to species for the Smooth-hound sharks genus Mustelus Link, 1790 (Chondrichthyes: Triakidae) from the Western South Atlantic. Panamjas 5: 401-413.

Saidi B., Bradai M., Bouian, A. 2008. Reproductive biology of the smooth-hound shark Mustelus mustelus (L.) in the Gulf of Gabes (south-central) Mediterranean Sea). J. Fish. Biol. 72: 1343-1354. http://dx.doi.org/10.1111/j.1095-8649.2008.01801.x

Saidi B., Bradai M., Bouian, A. 2009. Reproductive biology and diet of Mustelus punctulatus (Risso, 1826) (Chondrichthyes: Triakidae) from the Gulf of Gabès, central Mediterranean Sea. Sci. Mar. 73(2): 249-258. http://dx.doi.org/10.3989/scimar.2009.73n2249

Sant'Anna B.S., Watanabe T.T., Turra A., et al. 2012. Relative abundance and population biology of the non-indigenous crab Charybdis hellerii (Crustacea: Brachyura: Portunidae) in a southwestern Atlantic estuary-bay complex. Aquat. Inv. 7(3): 347-356. http://dx.doi.org/10.3391/ai.2012.7.3.006

Shing C.C.A. 1999. Shark fisheries in the Caribbean: the status of their management including issues of concern in Trinidad and Tobago, Guyana and Dominica. In Shotton, R. (ed.) Case studies of the management of elasmobranch fisheries. FAO Fisheries Technical Paper. No. 378, part 1. Rome. pp. 1-479.

Shing C.C.A. 2006. Shark fisheries of Trinidad and Tobago: A National Plan of Action. Proc. Gulf \& Carib. Fish. Inst. 57: 205-213.

Springer S., Lowe R. 1963. A new smooth dogshark, Mustelus higmani, from the Ecuatorial Atlantic Coast of South America. Copeia 2: 245-251 http://dx.doi.org/10.2307/1441339

Stehmann M. 2002. Proposal of a maturity stages scale for oviparous and viviparous cartilaginous fishes (Pisces, Chondricthyes). Arch. Fish. Mar. Res. 50: 23-48.

Tagliafico A., Rago N., Rangel M.S, et al. 2012. Exploitation and reproduction of the spotted eagle ray (Aetobatus narinari) in Los Frailes Archipelago, Venezuela. Fish. Bull. 110: 307-316.

Tagliafico A., Rago N., Rangel M.S. 2013. Biological aspects of rays Dasyatis guttata and Dasyatis americana (Myliobatiformes: Dasyatidae) caught by the artisanal fishery in Margarita Island, Venezuela. Rev. Biol. Mar. Oceanogr. 48(2): 365-373. http://dx.doi.org/10.4067/S0718-19572013000200015

Tavares R. 2009. Tiburones y rayas (Elasmobranquios): ¿Un recurso pesquero sobre-explotado en Venezuela? INIA Hoy, 4: 71-77.

Tavares R., Sánchez L., Medina E. 2010. Artisanal fishery and catch structure of the smalleye smooth-hound shark, Mustelus higmani (Springer \& Low 1963), from the northeastern region of Venezuela. Proc. Gulf \& Carib. Fish. Inst. Cumaná, Venezuela. 62: 446-449.

Walker T. 1998. Can shark resources be harvested sustainably? A question revisited with a review of shark fisheries. Mar. Freshwater Res. 49: 553-572 http://dx.doi.org/10.1071/MF98017

Wetherbee B.M., Gruber S.H, Cortés E. 1990. Diet, feeding habits, digestion, and consumption in sharks, with special reference to the lemon shark, Negaprion brevirostris. In: Pratt H.L., Gruber Jr. S.H., Taniuchi T. (eds), Elasmobranch as living resources: advances in the biology, ecology, systematics, and the status of the fisheries. NOAA. Tech. Rep. NMFS 90, pp. 29-47.

Williams A. 1984. Shrimps, lobters, and crabs of the Atlantic coast of the Eastern United States, Maine to Florida. Washington Smithsonian Institute Press, Washington, $500 \mathrm{pp}$.

Yamaguchi A., Taniuchi T. 2000. Food variations and ontogenetic dietary shift of the starspotted-dogfish Mustelus manazo at five locations in Japan and Taiwan. Fish. Sci. 66: 1039-1048. http://dx.doi.org/10.1046/j.1444-2906.2000.00166.x

Yamaguchi A., Taniuchi T., Shimizu M. 2000. Geographic variations in reproductive parameters of the starspotted dogfish, Mustelus manazo, from five localities in Japan and in Taiwan. Environm. Biol. Fish. 57: 221-233. http://dx.doi.org/10.1023/A:1007558324902

Zar J.H. 1996. Biostatistical analysis. Prentice Hall Inc., NJ, 662 pp. 